\title{
AUTONOMOUS MOTIVATION OF PROTAGONIST'S SELF DETERMINATION IN NICHOLAS SPARKS' THE BEST OF ME
}

\author{
Irma Oktia Waila, Sri Wulan \\ Faculty of Literature \\ Universitas Islam Sumatera Utara (UISU), Medan, Indonesia \\ E-mail: wailaarashi@gmail.com
}

Received: 2021-04-28

Accepted: 2021-05-24

\begin{abstract}
Nicholas Sparks' The Best of Me is a novel that tells the story of a love journey between Dawson Cole and Amanda Collier, who is forced to be blocked by Amanda's parents who do not approve of their love because of differences in social class so that in the end they have to separate. However, after being separated for so long they are reunited with different circumstances. The strength of this novel is the moral value of the main character. This study aims to examine the self-determination that exists in the protagonist. In examining this novel, the writers adopt descriptive qualitative research. There two forms of self-determination. They are autonomous motivation and controlled motivation. The study is focused only on the autonomous motivation of the protagonist's self determination in the novel. Two aspects are found as the protagonist's autonomous motivation. These aspects happen to the protagonist's love story in the novel. The first is loyalty and the second firmness of love. The protagonist shows his self-determination by means of two aspects.
\end{abstract}

Keywords: Self Determination, Autonomous motivation, Controlled motivation.

\section{Introduction}

The Best of $\mathrm{Me}$ is a romantic novel by Nicholas Sparks, an American novelist. The Best of Me was published in 2011. This novel talks about Dawson Cole and Amanda's pair of lovers when they are in senior highschool. After 20 years, they meet again in a house where their memories are in senior high school and that is Tuck's house. Tuck is an old man who meets Dawson accidentally when Dawson tries to escape from his father.

Dawson gets into Tuck's old garage and that is where they get to know each other. They live together. Tuck is a good man and takes care of Dawson. One day, Dawson has grown up and discoveres that Tuck has died. Dawson is sad because only Tuck he has at the time. Finally, Tuck hands over the little house to Dawson along with the beautiful garden of Tuck's wife relic. Dawson family has been famous since his grandfather has moonshiners business and his family is known as a cruel criminal family.

Dawson's love is when he can spend all his time with Amanda. From this novel, it is found that the protagonist shows self determination, that is the determination to 
love a woman by giving the best of him to Amanda and until the time he dies he only loves one. The one is Amanda.

Nowadays, it is rare to find a personality like the one possessed by the protagonist of this novel. It is not an easy thing to stand firm in our position. There are many obstacles, reproaches and even temptations that make us fall and change direction. Such obstacles also happen to the protagonist of the novel. He is a loyal person and firm in his stance. The protagonist shows self determination in his own love.

In life, self determination is very important. Even a lot of success comes from self determination, not only in the world of love, but also in the world of education, business, and even government. All success starts with determination. Finally, this leads to this study. This study is focused on the protagonist's self determination. Hopefully by reading the results of this research, useful moral values can be picked and this study may contribute other variables taken from the novel to analyze.

The analysis focuses only on the autonomous motivation of the self determination of the protagonist without discussing anything else about the character and also the self determination of other characters. Actually, there are two forms of selfdetermination. They are the autonomous motivation and controlled motivation. However, this study only discusses the autonomous motivation of the protagonist's selfdetermination in the novel. Theoretically, it is hoped that this study can be used as helpful reference in order to understand the novel The Best of Me by Nicholas Sparks.

\section{Literature Review}

Self-determination is a vital piece of psychological well-being; as you may expect,people generally like to feel in control of their own lives. According to Deci and Ryan quoted by Pintrich and Schunk (2002), self-determination is the process of utilizing one'swill.

Self-determination requires that people accept their strengths and limitations, becognizant of forces acting on them, make choices, and determine ways to satisfy needs.Will and self-determination are linked: To be self-determining, people have to decide how to act on their environment.

Another definition of self determination given by Little, et al in Wehmeyer and Abery (2013) is that Self-determination is a general psychological construct within the organizing structure of theories of human agentic behavior. Then, Wehmayer et.al in Wulan, et. al. (2019) defines self determination is a complex process the ultimate goal of which is to achieve the level of personal control over life that an individual desires within those are as the individual perceives as important.

It is nearly the same as Ackerman's description (2019). Self-determination theory is a general theory of human motivation that emphasizes the extent to which behaviors are relatively autonomous (i.e., the extent to which behaviors originate from the self) versus relatively controlled (i.e., the extent to which behaviors are pressured or coerced by intrapsychic or interpersonal forces). SDT defines motivation as psychological energy directed at a particular goal. Many theories of human behavior account for the direction of behavior, but fail to account for how that behavior is energized. SDT has thus emphasized the importance of motivational quality in addition to its quantity. It has also offered a particularly comprehensive approach to studying health behavior via its conceptualization and measurement of autonomy, perceived competence, relatedness to others, and its emphasis on the role of the social context in supporting or thwarting optimal motivation. 
SDT (Self Determination Theory) differentiates between autonomous motivation and controlled motivation. Autonomous motivation includes internal drives that motivate us to be have in certain ways, including our core values, our interests, and our personal sense of morality. Controlled motivation is external sources and results inexternal rewards. Such sources include grading systems, employee evaluations, awards and accolades, and the respect and admiration of others.(Deci and Ryan 2008 quoted by Wulan et. Al.,2019).

Sebire at. al in Wulan at.al (2019) describes the more self-determined types of motivation (i.e., intrinsic motivation, integrated \& identified behavioral regulation) are broadly grouped as autonomous. Intrinsic motivation is based on the inherent satisfaction or enjoyment that accompanies a given behavior. The other forms of autonomous motivation are extrinsic in nature and involve undertaking a behavior for a reason other than its inherent satisfaction. Integrated regulation is where a person aligns their engagement in a behavior with their broader self (e.g., seeing being active as part of one's identity) and identified regulation represents motivation which is driven by a valued outcome such as health benefits or making new friends.

Thus, this study concerns to the autonomous motivation of the protagonist's self-determination in the novel, and the above description becomes the literature background of this study.

\section{Research Method}

Study research are plans and procedures for research that span the decisions from broad assumptions to detail methods of data colletion and analysis (Creswell, 2009: 3). Therefore, research design adopted in this study is descriptive qualitative because the process of the analysis and the finding are accomplished descriptively. This study explores and understand the racial problems found in the novel.

There are steps conducted to gather the data wholly. In this study, the procedures are reading the data carefully, collecting the data obtained, identifying any account (data) from the study that are categorized the problems of this study, classifying the data into the points included in the subject matter of this study.

In analyzing the data, the writer needs procedure to the data collected as indicated: rereading the data, doing the analyzing systematically, taking the relevant quotations in accordance with the topic, analyzing the quotations to make them linked with the essence of the study.

\section{Discussion}

The first kind of self determination is autonomous motivation that includes internal drives that motivate us to be have in certain ways, including our core values, our interests, and our personal sense of morality. In this novel, the autonomous motivation of the protagonist is one of the strongest parts to encourage the protagonist who has self-determination. This autonomous motivation of the protagonist self determination includes two aspects. The first is loyalty and the second firmness. These loyalty and firmness are dedicated to the protagonist's love.

\subsection{Loyalty}

The first aspect of autonomous motivation found in the novel is loyalty. Loyalty is dedication; knowing that you're devoted solely to each other. That all of the choices 
and decisions you make have been considered with your partner and the impact on your relationship in mind. Your commitment never wavers and your bond is unbreakable.

The first part is the protagonist who has a loyal streak from being proven apart for 20 years he has never been interested in or dated any other woman. Such protagonist loyalty is presented below.

"What about when you go out? There are lots of great places to eat in New Orleans." "I hardly ever get to the city." "Even on a date?" she quizzed between bites. "I don't really date," he said. "Ever?" He began to cut his steak. "No." "Why not?" He could feel her studying him as she took a sip, waiting. Dawson shifted in his seat. "It's better that way," he answered. Her fork paused in midair. "It's not because of me, is it?" He kept his voice steady. "I'm not sure what you want me to say," he said. (Sparks, 2011:90)

The quotation above shows that Dawson is a loyal figure, and even after being separated for decades from Amanda. He keeps loving Amanda with all of his life while separating from Amanda. He has never dated any women because he has only loved Amanda so far. Moreover, the saddest part is when Amanda has become someone else's wife and mother of Jared.

A love story that is so sweet and extraordinary. Their love story is not about unrequited love. They are two human beings who love each other, as evidenced by the loyalty they have. Twenty years apart is not a short period of time; it is quite a long time, generally that long to let go or forget someone is a normal time. But it is different for them. Dawson loves Amanda sincerely, throughout his life Dawson still loves Amanda even though in the end he really did have to be separated forever from the woman he loved so much.

Not only in love, Dowson, the protagonist is also loyal to his friendship. He saves Alan' life, and he also has saved Amanda's kid, Jared. Besides, Dowson always tries hard to give his best to Amanda. The following shows it.

"How about a quick hug," she said, "before we go inside?" Jared rolled his eyes, but he opened his arms anyway. "I love you, Mom," he mumbled, pulling her close.

Amanda closed her eyes, feeling the steady rhythm in his chest. "I love you, too." (Sparks, 2011:387)

From the quotation above, it explicates that Dawson is really loyal to Amanda. Even, also with her child "Jared". While Jared has terrible accident and need a heart donor, Dawson is the person that gives his heart to Jared in order to keep him alive. Dawson loses his life to save Amanda's child is the proof of his forever love to her. All the above has proved that Dawson's loyalty keeps until his death.

\subsection{Firmness of Love}

The other form of autonomous motivation in the novel is firmness of love. Firmness in adults it is defined as a likelihood stable in the individual to strive for and use closeness with someone or certain people who give a potential subjective taste safe and protected against physical or psychological. 
Then the protagonist's autonomous motivation in this novel is firmness in love; the protagonist only loves a woman until the end of his life, he loves sincerely without expecting anything in return. It can be seen in the quotation below.

"Now, sitting on her porch as the late afternoon sun slanted through the trees, she closed her eyes and sent a silent message to him. She remembered his smile and the way his hand had felt in hers, she remembered the weekend they'd spent, and tomorrow, she'd remember it all once more. (Sparks, 2011:384)

The quotation above shows the firmness of Amanda and Dawson's love in the novel. It is seen when Amanda keeps remembering Dawson; she still remembers how she feels about him. She never meets a person as loyal as Dawson as his loyalty is everything in her life. It stays with her even when they have been separated and Amanda has new life with her family.

"I want to wake up with you beside me in the mornings, I want to spend my evenings looking at you across the dinner table. I want to share every mundane detail of my day with you and hear every detail of yours. I want to laugh with you and fall asleep with you in my arms. Because you aren't just someone I loved back then.You were my best friend, my best self, and I can't imagine giving that up again." $\mathrm{He}$ hesitated, searching for the right words. "You might not understand, but I gave you the best of me, and after you left, nothing was ever the same." (Sparks, 2011:267)

The above quotation also shows their firmness of love. When Amanda and Dawson meet they still show their love to each offer. Amanda is crying while she tells her imagination about their relationship. How if they are still being together it will be so good. All of this would not happen; all of these problems. Even when Dawson has gone for a long time, their love still remains the same.

"Here and now, though, in the quiet yellow light of an abandoned garage, he wasn't so sure. He'd loved Amanda once and he'd never stopped loving her. (Spark, 2011:101)"

From the quotation above, Dawson recognizes that he still loves Amanda and never stops loving Amanda even though at that time they have been separated. Dawson feels himself unworthy for Amanda because of the limitations he has, and he decides to leave Amanda's life. In front of Amanda, Dawson might be able to lie, but his heart and his feelings cannot be avoided. Dawson only loves Amanda.

Based on the analysis of the autonomous motivation of the protagonist's selfdetermination in the novel The Best of Me by Nicholas Sparks, there are some findings which can be presented. The analysis shows that self determination is found in the novel. The first factor of the protagonist's self determination is autonomous motivation. There are two forms of autonomous motivation of the protagonist's self determination: loyalty and firmness in love.

Dawson is a loyal figure, even after being separated for decades from Amanda. He keeps loving Amanda with all of his life while being apart from Amanda. He has never dated any woman because he only loves Amanda so far. Moreover, the saddest 
part is Amanda has become someone else's wife and mother of Jared. Dawson is really loyal to Amanda. When jared has a terrible accident and needs a heart donor, Dawson is the person that gives his heart to Jared in order to keep him alive. Dawson loses his life to save Amanda's child and this proves of his forever love to her.

All the above data prove that the protagonist shows his own determination in his love, and this self determination is because of his loyalty and firmness in his love. These two aspects belong to autonomous motivation.

\section{Conclusion}

Having done the analysis of protagonist's self determination portrayed in the novel The Best of Me by Nicholas Sparks, the writers come to the following conclusions From the analysis, The autonomous motivation in the novel is when Dawson has loyalty and firmness of love. First, it is found that Dawson is a loyal figure, even after being separated for decades from Amanda. He keeps loving Amanda with all of his life while being separated from Amanda. He has never make a date with any woman because he has only loves Amanda so far.

And, then firmness of love is also shown by the protagonist in the novel. Ddawson recognizes that he still loves Amanda and never stops loving Amanda even though at that time they have been separated. Dawson feels himself unworthy for Amanda because of the limitations he has, and he decides to leave Amanda's life. Dawson only still loves Amanda. Therefore, there are two aspects of autonomous motivation of the protagonist's self-determination in the novel. They are the protagonist's loyalty and firmness in love.

\section{References}

Ackerman, Courtney. (2019). What Is the Self Determination Theory of Motivation. https://positivepsychologyprogram.com/self- determinationtheory/\#whatselfdetermination.

Creswell, J. W. (2009). Research Design Qualitative, Quantitative, and Mixed Method Approaches. Los Angeles: SAGE Publications.

Pintrich, Paul R. \& Schunk, Dale H. (2002). Motivation in Education Theory, Research, and Applications 2nd edition. New Jersey: Pearson Education - Merril Prentice Hall.

Sparks, Nicholas. (2011). The Best of Me. New York: Grand Central Publishing.

Wehmeyer, M.L., \& Abery, B. (2013). Self-determination and Choice. Intellectual and Developmental Disabilities, 51(5), 399-411. https://doi.org/10.1352/1934-955651.5.399

Wulan, S., A., Hariani, S., Pratiwy, D., \&, P. (2019). Self Determination in Nicola Yoon'S Novel Everything. KnE Social Sciences, 3(19), 753-769. https://doi.org/10.18502/kss.v3i19.4902 